\title{
Museums and Museum Philosophy in China
}

Su Donghai

An overview is given of the origin, philosophy and current situation of museums and museology in China. Museums in China can be traced as far back as 478 BC.

However, it was only in the early period of this century that museums in the modern sense came into being. The development during the last 90 years was strongly influenced by the political events. In the first period of development up to the war of 1938 the number of museums passed 75. At the founding of the People's Republic of China in 1949 less than a third of these museums existed in mainland China. At the end of the 1950 s the number again reached the level from the 1930s.

The Cultural Revolution (1966-1976) was a disaster to Chinese museums. They were completely involved in political conflicts, the professional staffs had to leave, exhibitions and documentation were in many cases destroyed or changed at the will of politicians.

Since the last part of the 1970s there has been a huge growth in the number of Chinese museums. They now count a total of 1600. Professional activities have also increased including the foundation of the Chinese Society of Museums in 1982, with now more than 3000 members, and an active participation in ICOM activities since 1984.

\section{ORIGIN AND EVOLUTION OF MUSEUMS}

The museum is a kind of cultural phenomenon. How and when did it start? The museum originated from the collection of treasure. But the collection itself was not enough, a primitive museum only came into being when the collection attained a certain scale and had been stored in a special place. The Muses' Temple, founded in the 3rd century BC, was one of the earliest museums. It was a palace which embodied wisdom and intelligence and a high value was bestowed to "objets d'art» stored in this museum. We can say that from the very beginning, the idea of museum was connected with culture. The idea that 
SU DONGHAI

62 considers a museum a cultural palace remained alive for many centuries until the birth of the museum in the modern sense.

In primitive society, people knew nothing of private ownership and they shared everything. With the coming of the slave society, human beings entered into a civilised age. With the development of productivity, private ownership appeared and «objets d'art» emerged. Some people were zealous in their pursuit of such treasures and spcific places were built to collect and store them. This phenomenon is regarded as the beginning of the primitive museum.

Such primitive museums, with a private collection as their major characteristic, were born in the period of the Roman Empire, existed and developed strongly in Europe up to the Middle Ages. Influenced by the scientific revolution in the 16th and 17 th centuries, the democratic revolution of the 18th century and the industrial revolution of the 19th century, the museum experienced qualitative change. The museum was no longer a secret place for collected cultural relics, it was opened to the public and started its social progress. Two more functions - scientific research and education - were added to its original single function of collection, making it a museum in the modern sense.

The change from an ancient museum to a modern one was a process of criticism and inheritance, enabling a museum to keep a foothold in modern civilised society. In the next century, the 20th century a museum keeps its due cultural position through self-criticism and development.

The three functions of a museum, namely as collection, scientific research and education, have developed gradually in line with the social requirements.
Collection is the oldest function, scientific research only came with the appearance of modern science in the 16th and 17th centuries. As a result, some science museums providing original documents, instruments and sites for scientific research, emerged as required by the times.

Several museums started to collect objects used for scientific research and assembled them in a systematic way. Study of the collection has become a key subject in scientific research. The growth of the scientific research function of museums encourages scientific research of the museum itself. Thus bringing about museology. The earliest form of museology is the science of the types of museum. The emergence of the scientific research function has enriched the cultural content of the museum and promotes the scientific progress of the museum proper.

In the 19th century, the museum was granted a new function - the educational. In 1851, the Great Exhibition held in London displayed the fruition of the industrial revolution and the scientific accomplishments achieved in many countries. Some men of foresight began to recognise the educational value of a museum. In 1873, the British Royal Arts Society put forward the suggestion to: «let all public museums have education and scientific research as their targets." Thus, the educational function of the museum was gradually developed. The co-existence of the three functions has enlarged the museum's cultural connotation, reinforced its position in society and injected into it more life and vitality. The 19th century saw the first high tide of museum undertakings.

The three functions were born successi- 
vely in the developing history of the museum. The first and oldest function is the collection of treasure. The second function is scientific research which is not a negation but an extension of the first function. Scientific research is done on the base of the collected objects and these objects are the carriers of scientific information in a museum. Therefore, if there are no collected objects there is no scientific research function.

The same is true of the third function the educational. A museum carries out this function by exhibiting and displaying its collected objects, a method which differs from other kinds of educational methods. So the third function is an extension of the first and second functions. There is a logical relationship among the three functions, which can be illustrated by concentric circles. The centre represents the treasure-collecting function, the second circle the scientific research function and the outer one the educational function. Optimal efficiency for a museum can only be achieved by giving full rein to all the three functions.

These three functions have not been created by any one person but are an outcome of historical development and social progress. I believe the museum will make further conversions in the future with the coming of the new social civilisation but its essential character will continue to survive.

\section{HISTORY OF CHINA'S MODERN MUSEUMS}

The museum originates from the treasure collection and China has a long history of treasure collection. Archaeologists have discovered underground treasure houses at the site of the capital of the Shang Dynasty (16th-11th BC). In the 11th century BC, the Zhou Dynasty began to store precious objects in the Temple of Ancestors. But the earliest recorded primitive museum in China is the Temple of Confucius in the sage's hometown of Qufu, in Shandong Province. Confucius (551479BC), a great thinker in ancient China, died in $479 \mathrm{BC}$. In the second year after his death, his former residence was rebuilt as a temple for worship and offering sacrifices to the sage. Exhibited here were his clothes, hats, musical instruments and carts. This temple is one or two centuries earlier than the Temple of the Muses.

Emperors from all the Chinese dynasties had special structures to house their precious cultural curios. Starting with the Song Dynasty (960-1279), private collections have turned up. The study of collected objects developed rapidly. Great achievements were made in bibliography and the identification of antiquities and many books were published. At that time, China had attained a certain degree of achievement in the sorting and registration of cultural relics.

For the past 2000 years in China both royalty and private people have been active collectors. The collections were impressive both in quality and quantity. At the same time, the study of collections and storage techniques were greatly improved. But until the end of the 19th century, China had no modern museum. Why? I consider that the modern sense of the museum is an outcome of industrial civilisation. Museums in the primitive sense cannot turn into modern museums unless they have gone through the test of modern science and democracy. Traditio- 
SU DONGHAI

64 nal treasure-collecting and ancient museums have existed for more than 1000 years since the period of the Roman Empire. Yet during this long period, no modern museum with all the three functions emerged. Only the industrial civilisation could prepare the historical ground for a museum in the modern sense. In China feudalism lasted until the end of the 19th century, so the conditions for a modern museum did not exist. In the global developing process, Europe was advanced and the East was backward. That is why no modern museum could appear spontaneously in the lands of China, India or even Japan. China lagged behind in the establishment of modern museums as a result of its later industrialisation.

Museums in the modern sense came into being in China at the early period of this century. Over the past 90 years Chinese museums have undergone three important periods of development: the 1930s between the two World Wars; the 1950s after World War II, and the contemporary 1980s and 1990s. These three periods of development for museums were also experienced throughout the world within the present century. Compared with the situation of museums in Western countries, however, Chinese museum development always lagged ten or twenty years behind as a result of historical conditions in China. A bird's-eye view of above mentioned three periods of development is given below.

\section{THE FIRST PERIOD OF DEVELOPMENT}

It was not so late in the 19th century that China considered the establishment of museums. As early as in the 1860 s and 1870 s, China had launched a campaign to learn from the West almost simultaneously with Japan, and started the process of social modernisation. The establishment of Western-style museums was considered an effective measure for «developing people's intelligence». But the Chinese modernisation campaign was strangled by the corrupt domination of the Qing dynasty (1644-1911). Although a few museums were set up in China by the French or English or other foreigners such as the Shanghai Xujiahui Museum founded by French missionaries in 1868 and the Asian Cultural Association Museum established by an Englishman in 1876, the Qing government was not in favour of these kinds of facilities. Mr Zhang Jian who was the pioneer in the building of Chinese museums was refused when he appealed for permission to establish a Chinese imperial palace museum in Beijing, capital of China, in imitation of the Japanese Imperial Museum. Later, in 1905, he set up at his own expense the first private museum in China - the Nantong Museum, inaugurating the era of modern Chinese museum undertakings. The Revolution of 1911 , led by Sun Jetsen, overthrew the rule of the Qing Dynasty and established the Republic of China and built the first Chinese national museum - The Museum of Chinese History. Unfortunately, the government of the Republic of China was soon replaced by a government of warlords and China subsequently fell into a period of tangled warfare among the warlords. Finally in 1928, Jiang Jieshi united China. His government underwent a period of development in the 1930 s which coincided with the develop- 


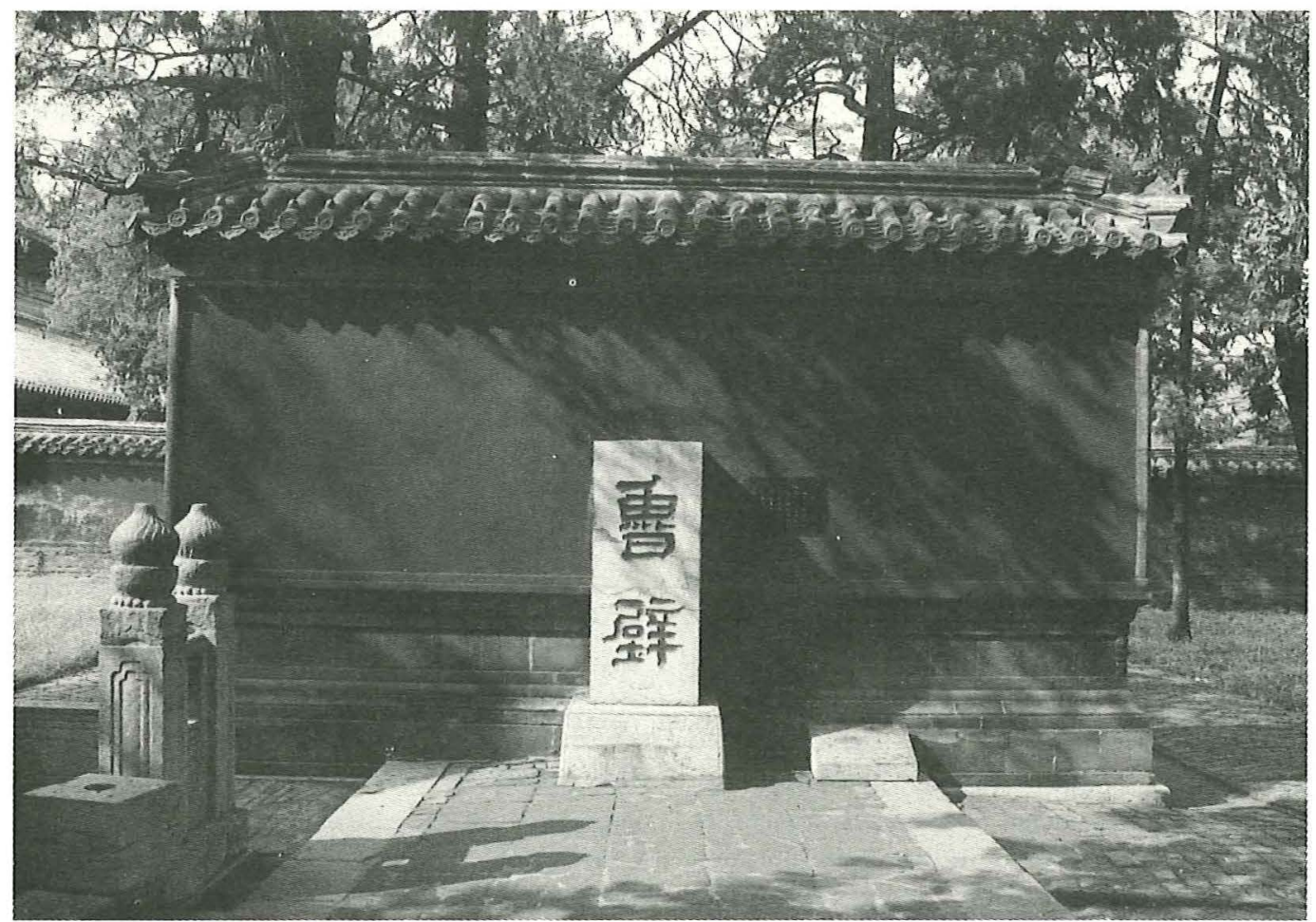

$L u B i$, the oldest part of the Temple of Confucius in his hometown Qufu, in the Shandong Province was established in 478 BC as a memorial hall where the clothes, musical instruments and other objects used by Confucius were exhibited. It is now a site museum.

ment of the museums. This is the first period of development for Chinese museums. According to the statistics, there were 10 museums throughout the country. By 1936, the number of museums in the country reached 77 , with an average increase of $29 \%$ for each year. At that time, museums were so active professionally that there were 215177 collection items in Beiping (now Beijing) History Museum. From 1928 to 1934, Beijing Antique Exhibition Hall received in total more than 420000 visits. Chinese museums also exhibited abroad, participating in international activities.

In 1935, the Chinese Association of Museums was founded for the purpose of museological studies and published $A$ Guide to the Chinese Museum and The Catalogue of Museological Publications and a few other museum or museological publications. The 1930 s was a decade when Chinese museum work was full of promise and museology rose in China. 
SU DONGHAI

66 Unfortunately the Sino-Japanese War (1938-1945) and World War II suspended a process that was full of hope.

\section{THE SECOND PERIOD OF DEVELOPMENT}

After the founding of the People's Republic of China in 1949, the Chinese government attached importance to the development of museums. Shen Yanbing, the former Minister of Culture issued instructions on the constructive policy, tasks, nature and orientation in development for local museums. In addition many state leaders made observations on museums. There were only 21 museums left in mainland China when the new Chinese government was set up. But according to the statistics by 1952, the number of museums above and at provincial and city levels throughout the country had increased to 40 . At the end of the first Five-year Plan (1953-1957), the total number of museums had risen to 72 . Apart from Qinghai province and the Tibet autonomous region, every province roughly had established its own museum(s). The unbalanced situation with museums grouped in a few big cities in old China had been basically changed.

For the 10th anniversary of the founding of new China in 1959, the government made an immense allocation for building a series of national museums: the Museum of Chinese History, the Museum of the Chinese Revolution, Central Natural History Museum and the Chinese Military Museum. All these museums were both funded and supervised by the state or local governments. The museum staff members were also designated by the governments. Under such circumstances, the existence and development of museums was basically dependent on the needs of society and the government. A museum hardly had any decision-making power of its own. When the government called for the "march towards science», as a response particular attention was paid to providing services for scientific research by museums. When the class struggle was exacerbated the museum became one kind of political instrument.

During 1966-1976, the period of the Cultural Revolution, museums were involved completely in political struggles. At this time historical relics collected in museums were considered to be behind the times and reactionary. The historical exhibitions were considered eulogies of the ruling classes of the old China. Major parts of museums had to be closed for years and museum staffs had to go into the countryside to take part in physical labour. Meanwhile, many revolutionary memorial halls were set up on revolutionary sites. When the Red Young Soldiers (an organisation of middle school students during the Cultural Revolution) disbanded their activities museums were successively re-opened. Since the closing and opening of museums depended on political struggles history could be re-written and the exhibits could also be supplemented or removed at the will of politicians. For example, the signature of a historical figure who was politically condemned at a certain time would immediately be deleted from a historical document. The scientific and factual qualities of museums were heavily infringed. The very essence of museums was endangered. 


\section{THE THIRD PERIOD}

\section{OF DEVELOPMENT}

The Third Plenary Session of the Eleventh National Congress of the Communist Party of China held in December 1978 opened a new path for China to advance down towards modernisation. Under the guidance of the new state policy of reform and opening up to the outside world, Chinese museums met the third developing period. Compared to contemporary museums abroad which developed after World War II, Chinese museums of the 1980s lagged behind by two or three decades. Therefore, China is quickening its steps in the construction of museums. The requirements for the development of Chinese museums have been incorporated into such important documents as the Constitution of China and the Five-year Plan for National Economic and Social Development. Since 1977, the State Bureau of Cultural Relics of China has organised a series of nationwide professional conferences to promote the building (rebuilding) and development of museums.

On the basis of negation of the Cultural Revolution, the National Conference on the Work of Museums which took place in 1979 issued The Working Regulation of Museums at Levels of Province, City and Autonomous Region in which the object-factual quality of museums was reemphasised. Chinese museums have and still are ridding themselves of the political dimension and the cultural essence of the museum is being restored and developed. The multifunction and multivalue of museums is being brought into play in China. Over approximately the last ten years, museums have developed considerably in terms of number, quality and type. The statistics show that more than 1000 museums have been established since 1980. During the period 1980 to 1985 one new museum was set up every ten days, and particularly, in 1984, one new museum opened on mainland China every 2.4 days. Since the late 1980 s, this increase in museum numbers has slowed down but remains at ten per cent. Up to the end of 1993, the number of museums funded and supervised by the Chinese governments at different levels reached 1130 .

It is reasonable to believe that the total number of all types of museums throughout China has grown to 1600 . In 1982, the Chinese Society of Museums (CSM) was founded. Since then, nationwide activities in museum and museological research have been strongly promoted among the more than 3000 CSM members. Furthermore, the Chinese museums are advancing into the international museum world along with China's increasingly active participation in ICOM affairs since 1984

\section{PHILOSOPHY OF CHINESE MUSEUMS: \\ 1.THE OUTLOOK ON THE ESSENCE OF CHINESE MUSEUMS}

What is the essence of museums? Such a question attracts great attention in Chinese museological circles. In China, the beginning of intensive studies on this question can be traced back to the 1950s. The National Conference on Museum Work, held in May 1956, emphasised this question and gave an answer to it. The Conference, with 110 delegates, presented 
a famous point, known as the theory of the 'Three Natures and Two Tasks'. It is understood that museums have three basic natures, namely: scientific research institutions, cultural-educational organisations and, main agents for collecting and preserving spiritual-cultural relics as well as natural specimens. Thus, a museum is made by combining all these three natures. A museum also has two fundamental tasks, namely: to provide services for scientific research and to serve the broad mass of the people as a whole. Following the discussions of the above-mentioned conference, Zheng Zhenduo, a famous Chinese scholar and the then Deputy Minister of Culture PRC, delivered his concluding speech in which he made a further point that the three fundamental natures of museums, combining scientific research, cultural education, and collection and preservation of cultural relics and specimens, reflects an indivisible dialectical relationship among them. Consequently the essential characteristics of museums should be attributed to simultaneously containing within themselves all these natures. Zheng's speech clearly indicated that the three natures of museums represented an organic system, or an organic structural entity. Thus the essence of museums is a compound entity composed organically of the three natures. Lacking any one of them, a museum can no longer be a museum in its integrated meaning, nor can possession of any one of the three natures make a museum. Only with the existence of all the three, a museum can be a museum in its true sense. The organic existence of these three natures constitutes the essential characteristic of museums which makes them different from other institutions. Based on the results of the above-mentioned discussions, we hold that as early as in the mid 50s, Chinese museological circles had already given an answer to the question regarding the essence of museums, through analysing the museum structure. Of course, the recognition derived from that was at a primitive stage. As the practice develops, the recognition develops too.

The National Conference on Museum Work in the mid 50 s was convened soon after the CPC and the Chinese government had made the call to "march towards science", at a time when particular attention was attached to the museums and libraries providing services for scientific research. Thus, the three natures of museums had been stated as a way of bringing scientific research to the forefront, stressing that "scientific research is the foundation of all activities of museums" at the same time.

During the $60 \mathrm{~s}$, political struggles in China had been intensifying, culiminationg into the more serious situation at the time of the Cultural Revolution. Hence, the expositions of museums had to shift in order to follow closely political needs. History could be rewritten at will, exhibits could be amended and falsified at will.

After the Cultural Revolution, the museums went into a period of retrospection for some time, thus deepening the recognition of their essence anew. Chinese museological circles reconstructed the theory of «Three Natures and Two Tasks» by transforming the old sequence «scientific research, education, collection and preservation of cultural relics and specimens» into a new sequence - «the collection and 
preservation of cultural relics and specimens, education, scientific research». This new sequence gives a high priority position to "the collection and preservation of cultural relics and specimens» by bringing it to the forefront. Such a sequence was reflected in the new museum regulations promulgated in June 1979. In fact, the new sequence of the three natures not only reflects the change in order, but also indicates a leap in the recognition of the essence of museums at the same time. To accentuate the position of objects means to accentuate the core characteristic of museum. The other two characteristics of museum, i.e. scientific research and education, can only on condition they link themselves with the characteristic of objects and thus combine organically with it, form altogether a special compound entity known as a museum. Such a new recognition of the position of the characteristic of objects in the compound entity is a conclusion derived from long-term practice. It shows that the recognition of the museum essence inside the Chinese museological circles has been deepened by traversing a path from studies on the structure of museums to studies on their functions.

My own views relating to the relationship between the three natures have already been expressed in my article The Outline of Museum History, published in 1988. I hold that the three natures of museums have been shaped historically and not by any one person. In the historical process of museum formation, the function of collecting and preserving objects appeared earliest, it was the most ancient and also the first function of the museums. Object collection and preservation represent the core of the multiple nature of museums. lose their most essential characteristic. After this first function, scientific research appeared as the second function of museums. Social development needs science and technology, but the latter could not have takeen root in such a specific cultural body as the museum without the help of objects. For museums, objects are the carriers of scientific information. Without them, the museums would lose their scientific research characteristic and consequently lose their particular existensial value as the basis of scientific research as well as scientific popularisation. Social education appeared as the third function of museums. Such a function could by no means have been transplanted into museum soil without some foundation. It is the extension of the first and second functions innate to museums. The education provided by museums is a kind of education surrounding objects, or, an education of objectification. Only by means of surrounding the objects closely, is museum education able to fly its own colours and appear brilliantly among various kinds of education. In the course of the historical development of museums, the functions of the three natures appeared objectively and subsequently.

For decades the recognition of the essence of museums has been gradually deepening in Chinese museological circles. However, a matter does not have just one essence, more essences can be abstracted from the complicated phenomena of a matter. So far as I know, Dr. Peter van Mensch holds that to provide information is the most essential characteristic of the museums. In China, some researchers also 
SU DONGHAI

70 raised new viewpoints relating to this matter however I am not going to go over them here.

\section{THE VALUE OUTLOOK OF CHINESE MUSEUMS}

In China, the museums were originally introduced from the West. The Chinese also started to realise the value of museums through their observations of the museums in Western countries. In the 1860s China and Japan almost simultaneiously started the process of learning from the West. The investigators as well as the diplomats and students sent abroad by the Chinese government, usually attached great importance to the museums in the course of their observations of Western cultures. They usually held that the real objects-exhibits displayed in the Western museums could help people widen their field of vision and improve their knowledge, as well as benefit them by raising their scientific and cultural levels. During that time, China was in a state of crisis, being carved up by foreign powers, and the Chinese people were seeking a way of saving their country and making her strong, so, it was quite natural for the investigators to look first at the scientific and educational values of the museums, seeing them as a necessary means of reforming Chinese society. Thereafter the Chinese started setting up their own museums, and 42 museums were built successively up to 1937 .

All these museums were basically built by the governments. Why did the governments want to build museums in dozens of large cities throughout the country? Because the governments as well as those prudent people who were zealous in museum work, thought the scientific and educational values of museums were necessary for social transformation. Thus, being the carriers of these values, the museums were destined to be born and develop in order to meet social demands. With hindsight we can see that the Chinese museums were born and developed to carry out special social missions. The value of their existence lies in their realising the missions assigned to them by society. So, from the very beginning of their existence, Chinese museums became the museums of the mission type.

After the founding of the People's Republic of China in 1949, the new government of China attached great importance to the museums and a great number of museums were built through state funding. Apart from two remote regions, namely Tibet and Qinghai, museums were set up in all provinces, large cities and autonomous regions. During a period when China was learning from the Soviet Union whose museums were distinguished by strong socialist ideology, the value outlook of Chinese museums was inevitably influenced by the value propensity of Soviet museums. At this stage of development, political value became the main factor for the existence and development of Chinese museums. The political remoulding of the museums and the ideological remoulding of the museum professionals in the $50 \mathrm{~s}$, the stress on the necessity of making cultural relics and exhibitions available to serve the political struggles of the $60 \mathrm{~s}$, all these were the fruits born of political propensity. From a theoretical point of view, value belongs to a category of relationships. The govern- 
ment and society represent the subjects in the value relationship of the museums. The demands of the subjects play a leading role in shaping the value propensity. While the museums, representing the objects in the value relationship, remain the material carriers of the value. Yet, the value is latent and can be realised only through satisfying the demands of the subjects. In spite of the dependence of the value relationship on the demands of the value subjects, nevertheless, the value objects by no means play a completely passive role in realising the value. They can adapt themselves actively to the demands of the value subjects or even change them. The value subjects and the value objects interact with each other. In the time of the Cultural Revolution, some museums went so far as to fabricate history and remould the cultural relics at will in order to meet the demands of the political struggle. As a result they won the high estimation of the then value subjects and thus had a better chance of survival and development for a time. Of course, satisfying the special demands of the value subjects by means of distorting of the museum value was something that happened only under special political conditions.

In 1979, China entered into a new historical period with economic construction as the central task. Class struggle was no longer the key link in social life, consequently, the value propensity of museums was changed too. The museums resumed their cultural essence again. Being the show windows of the country, museums attracted attention from government and society. Chinese museological circles are experiencing a new upsurge in relation to studies of the cultural essence and functions of the museums, and on the assessment of their value as well as the value of cultural relics. Here, I would like to express my own views on the values of museums.

The values of museums are manifold both in kind and in stratification. There are huge value potentialities hidden in the museums which need the value subjects to be discovered and exploited. Viewed from the angle of a broad social cultural stratum, I hold that the museums possess four cultural values as follows:

\section{The value of verifying history}

Man's knowledge of both social and natural history is indirect, rational and not intuitive. Yet the items of museum collections are usually the original and tactile objects or materials related to past history. Through examination and research of these original objects and materials, people are able to sense and gain direct access to the past. Furthermore, as these original objects and materials are the survivors of history, they are able to verify it. Also, as they are the fossils of history and reflect it in materialised forms they undoubtedly possess an objectivity and reality which give them a very special value for people wanting to know and sense history. When standing in front of the magnificent arrays of clay soldiers and horses of the Qin dynasty, people cannot but be shocked by the force of history, an amazing feeling they can experience nowhere else except in a museum. These historical verifiers are called cultural relics and those collected and preserved in museums are the most selective ones with higher values for histo- 
72 rical memory and verification. Museums represent the centres of various precious cultural relics. The objects and materials with value for historical verification collected and preserved only in museums, are waiting for the value subjects to realise and to use them.

\section{The value of knowledge}

The objects housed in the museums belong to a particular sort of knowledge carriers and possess the special charms of knowledge. The displays and exhibitions organised by museums represent a unified body combining thinking both in terms of images and of logic and thus forms a special knowledge system of its own. Owing to their special value in providing knowledge as such, the museums are able to attract to themselves researchers and learners from various social strata.

The knowledge and information provided by museums is different in some way from that provided by research institutes and libraries. This is because they are not knowledge carriers, similar in all aspects. But, the knowledge and information provided by museums can be used side by side with that provided by other institutions on the basis of mutual supplement and verification. So, from the view of education, museums deserve to be openly admitted as class rooms, second to education in schools. Viewed in the light of scientific research and popularisation, the objects collected and preserved in museums provide important supplementary knowledge to that in books. Hence we can say, the museum is a special treasury of knowledge.

\section{The value of aestheticism}

Chinese society has not yet paid enough attention to the aesthetical value of museums. When museums were being introduced into this country, people attached great importance to their scientific educational values and neglected their aesthetical value. In the early 20th century, the Chinese scholar Cai Yuanpei, when studying in Germany, repeatedly stressed the aesthetical value of the museums. However, his voice did not attract enough attention from society. Since the $80 \mathrm{~s}$, Chinese society has started paying attention to the aesthetical value of museums. Some researchers have shown their concern over this issue already. Yet, at the moment, the aesthetical value of museums has still not been fully appreciated by the aesthetical subjects. The solution lies in the promotion of the aesthetical consciousness of society as a whole.

It is necessary to point out here the differential of aestheticism. There is different aesthetical consciousness under different ideologies. Accordingly, the aesthetical experience is also different against different cultural backgrounds. Such differences among the aesthetical subjects by no means lessens the possibility of realising the museum's values, on the contrary, it enables museums to exert greater attraction for visitors from different countries and places, thus realising their aesthetical value on a larger scale. Museums can satisfy not only the aesthetic requirements of domestic visitors, but also those of foreign visitors. 
MUSEUMS AND MUSEUM PHILOSOPHY IN CHINA

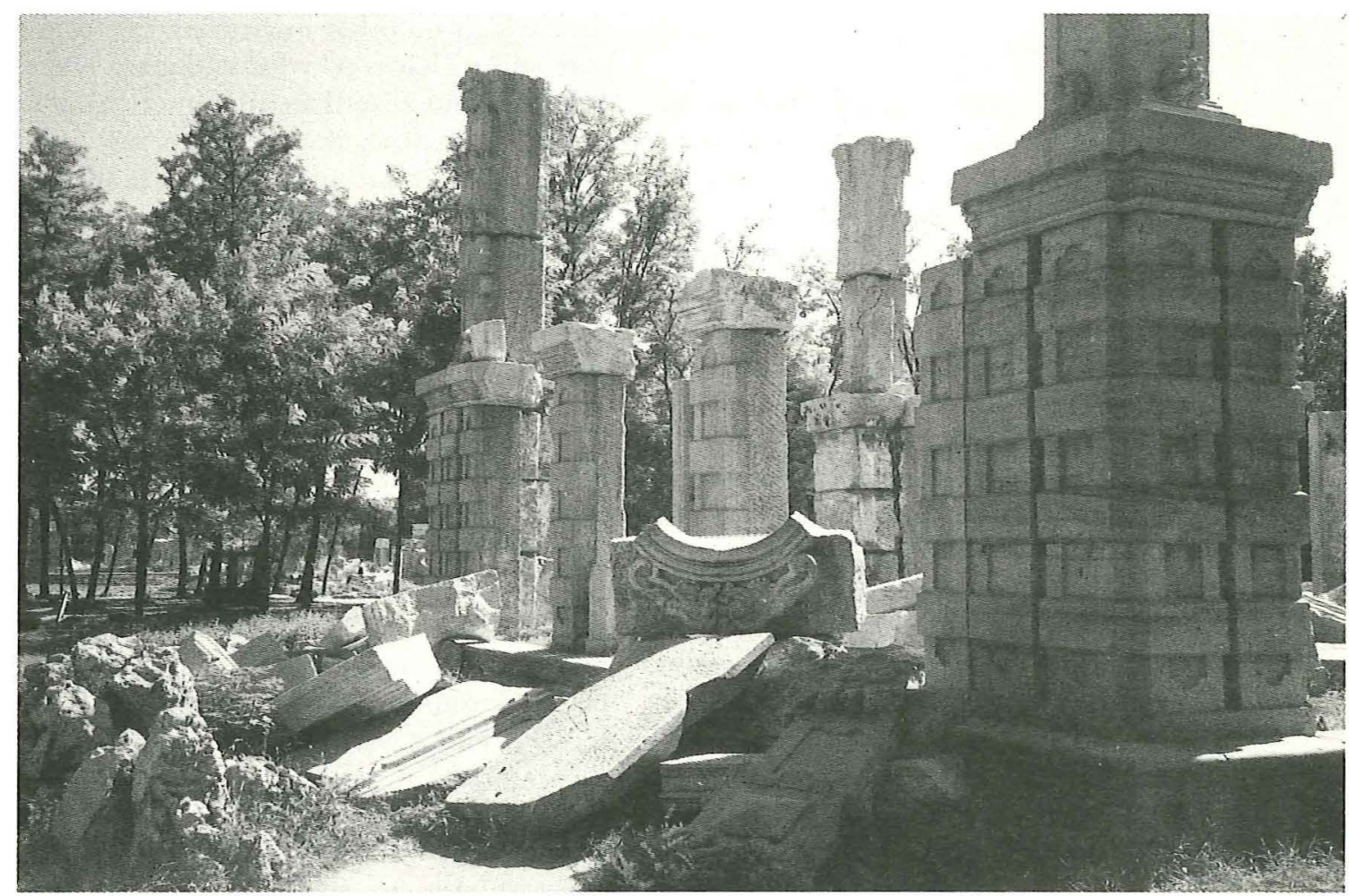

One current museological project in China is the preservation and partly reconstruction of the Emperors' old summerpalace, Yuanmingyuan. The emperor Qianlong had it made during his reign (1736-1795). He wanted to demonstrate the values of Western culture, and helped by the Italian architect Gastiglione he erected several palaces in Western style. During the Second Opium War (1856-1860) French and British troups destroyed the garden and the palaces. Photo: John Aage Gjestrum.

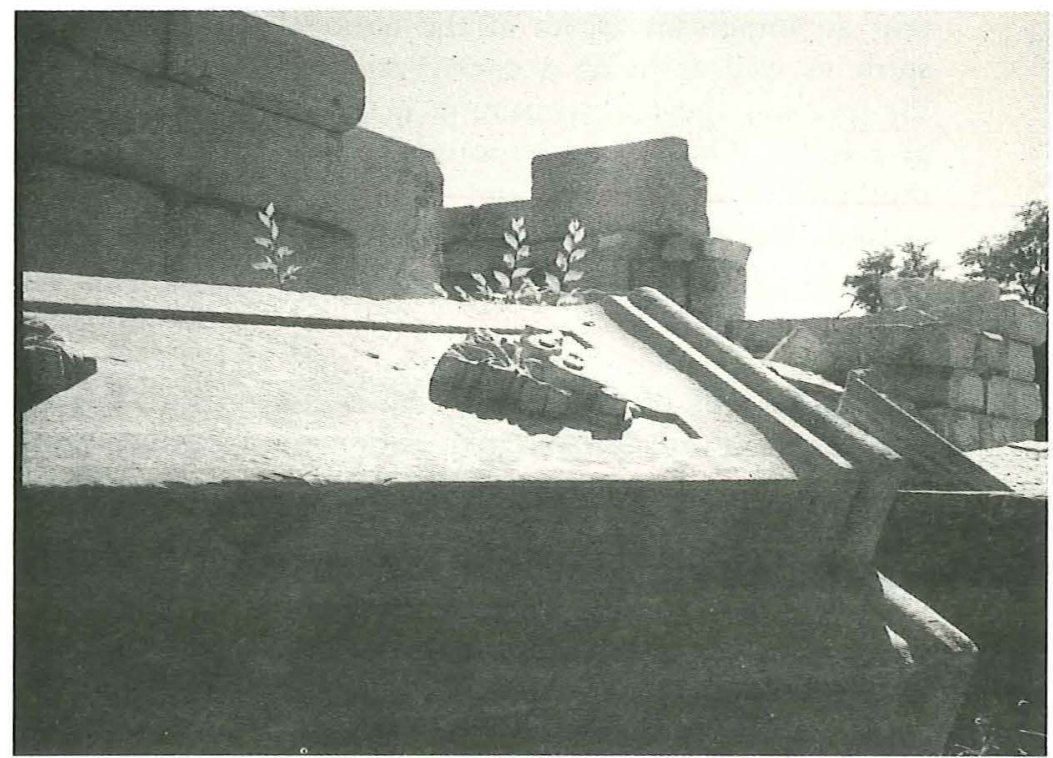


SU DONGHAI

74

\section{The value of morality}

Chinese society pays more attention to the moral value of museums. On their part, Chinese museums work rather hard to extol virtues such as patriotism, collectivism and selfless devotion by means of their displays and exhibitions. The Chinese government even established a number of museums dedicated specially to heroes and exemplary figures, such as Lei Feng and many others, for the purpose of extolling and publicising their communist virtues and glorious deeds. The Chinese government also pays great attention to setting up museums in honour of great and famous men and women in history, for the purpose of raising the moral status of the visitors to a higher level through the subtle influence of the thoughts, characters and deeds of these historical figures. The moral value acts in co-ordination with the aesthetic value. Some moral values are esteemed as virtues. Virtues represent an important aspect of the national spirit as well as being a contribution to the precious spiritual treasure of mankind as a whole. One of the responsibilities of museums is to publicise and extol these virtues. The moral value of museums lies precisely in eulogising noble deeds, characters and ideals.

The four kinds of values as we have discussed above are interrelated with one another. The value of verifying history and the value of providing knowledge can be expressed traditionally as 'truth', the value of morality as 'goodness', and the value of aestheticism as 'beauty'. So, the museums are the carriers of the values of 'true', 'good' and 'beautiful' at the same time which no other institution can compete with. That is why museums are more colourful and alive than any other cultural carrier. Therefore, the museums are praised as the cultural miniatures of mankind as well as the show windows of the spiritual civilisation of a nation.

\section{THE ETHICAL OUTLOOK OF CHINESE MUSEUMS}

In the field of practical ethics, a number of branches have been developed, such as medical ethics, legal ethics, business ethics and political ethics, etc., this situation cannot but provide an impetus for the establishment and development of museum ethics. The studies of the Code of Professional Ethics carried out by ICOM reflect the efforts dedicated to museum ethics research.

The ethical thinking and the remarkable Chinese inheritance of both the historical and revolutionary traditions are both present in the Chinese museums. They attach great importance to establishing people's relationships as well as fostering their thinking in terms of the ethical norms. Thus, the Chinese museum professionals who have been working in their field for a long time are people of high professional morality and refinement. Their behaviour is mostly controlled by moral force rather than legal force. The ethical idea of Chinese museums can be reflected mainly in three aspects as follows:

\section{'An Pin Le Dao'}

'An Pin Le Dao' is an old Chinese idiom expressing a traditional Chinese virtue. It can be rendered into English as 'to regard 
poverty with equanimity and to find pleasure in keeping to one's course'. To put it into contemporary language, 'An Pin' means to regard the material scarcity with equanimity, while 'Le Dao' means to devote oneself to one's ideal and to deeply love one's career. In fact, museum work is itself that with scanty material resources, with low pay and returns, especially in China. It really is a virtue for Chinese museum workers to undertake such work and set their hearts on it for a long period of time. A great number of Chinese museum workers even devoted life-long service to this undertaking, neither changing their minds nor being attracted to other jobs with higher pay. What makes them adhere so firmly to such a field with material scarcity and low pay? The explanation is that there are special professional attractions and unusual qualification demands in this field. As museum work requires high professional skills which can only be obtained through long-term accumulation as a rule, the longer the workers accumulate their knowledge, the higher the professional skills attained. Therefore long-term stabilisation of staff members is a professional requirement of museum work and accordingly, museum workers should be mentally well- prepared to have a life-long career with little material wealth.

This actually means making a personal sacrifice. Furthermore, 'to regard poverty with equanimity'( An Pin) must be linked with 'to find pleasure in keeping to one's course'(Le Dao). If it is not, the former loses its sense and value. The ancient Chinese philosophers, Confucius and Mencius, both thought highly of Yanhui's virtue of 'An Pin Le Dao', yet turned their sights on 'Le Dao'. It is mainly because of a noble professional responsibility and 75 love that we museum workers are able to regard material scarcity with equanimity. Museum workers always share a professional pride and experience a feeling of nobility in their work. The reason is that the museums are linked with things that are 'true, good and beautiful', and with the glorious history of a state and a nation. National pride combined with professional nobility creates a specially attractive power for the museums, which in turn enables museum workers to find pleasure in dedicating themselves to their course without being scared by material scarcity. Thus, the thinking and feeling of 'An Pin Le Dao' represents the ethical mainstay of Chinese museums.

\section{Prefer justice to profit}

The relationship between justice and profit is a traditional theme of Chinese ethics. Justice stands for the ideal of morality, while profit stands for economic gains. Traditional Chinese ethics prefers justice to profit. The Communist Party of China also thinks highly of setting up the idea of serving to the people wholeheartedly. Therefore, over a long period of time, Chinese museums, in accordance with their ethical thinking and practice, uphold the idea of selfless devotion to the public and regard it as a glorious deed to submit individual interests to collective interests. Moreover, they think that haggling over monetary reward and individual interests is unfitting conduct and so give no thought to it. The noble ideal and professional dignity have become the motive force in work while material incentive has been debased to an immaterial position. 
SU DONGHAI

However, as China is now in the course of establishing a socialist market economy, the ideas of ordinary people regarding moral values are changing too. Greater and greater attention is being paid to monetary rewards for work. The moral concept of 'preferring justice to profit' is being replaced by a value outlook 'combining justice and profit into one'. But, the unification of things in practice cannot be attained as easily as in thought. The contradiction between justice and profit remains a problem throughout the world and will only be solved gradually in the course of practice. For example, is saying that 'a museum is a non-profit-making organisation', an economic problem or an ethical one? And, what is the relationship between social effects and economic effects? All these appear to be complicated problems in practice.

The relationship between justice and profit can be extended into the relationship between collectives and individuals. Chinese morality attaches great importance to collective interests. To submit the interests of the individuals to that of the collective is regarded as an ethical norm in China. For Chinese museum professionals, collectivism is an important aspect of their moral accomplishment.

\section{Self-cultivation}

In China, to conduct self-cultivation, in other words, to attain moral refinement by oneself, is also a traditional virtue. The Communist Party of China emphasises the self-cultivation of party members. Ever since the CPC came to power, the Party and the state never ceased their efforts to uphold such a good tradition,

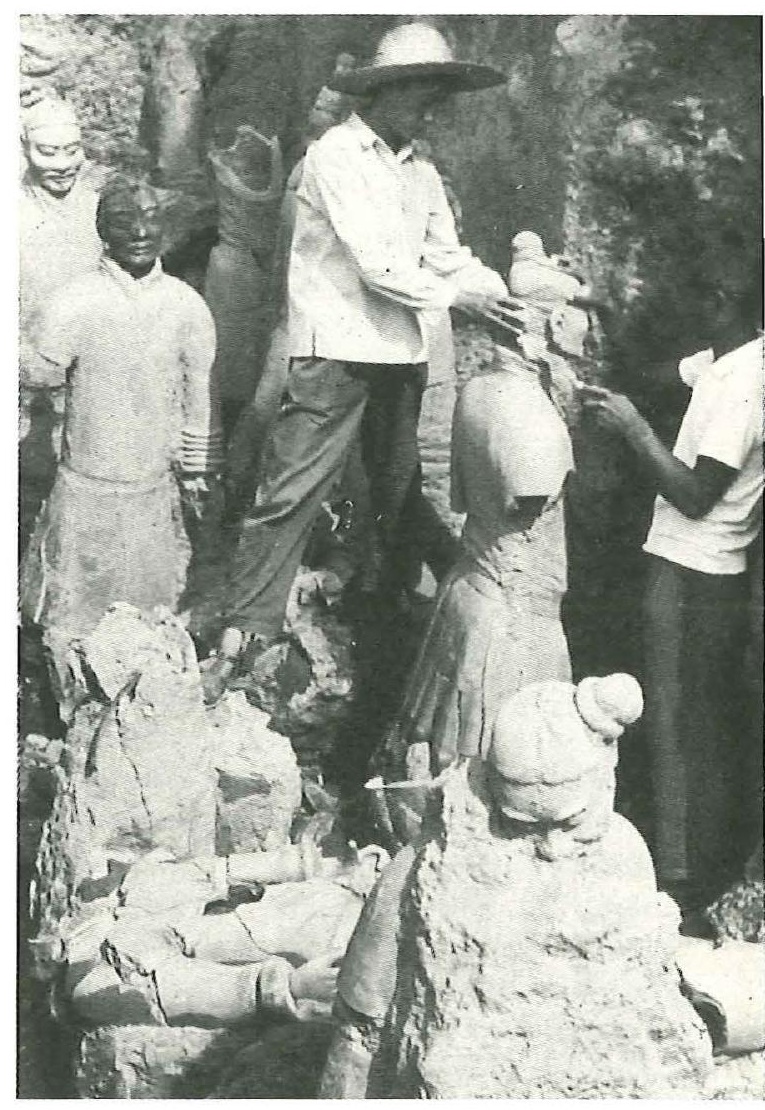

The Museum of the Terra-cotta Army, near Xian in the Shaanxi province, has been erected on the burial pits of the first Chinese Emperor Qin Shihuang. The three pits were discovered in 1974 containing more than 6000 fullsize warriors. The third large museum building was opened in 1994. Photo: The Museum of the Terra-cotta Army. 


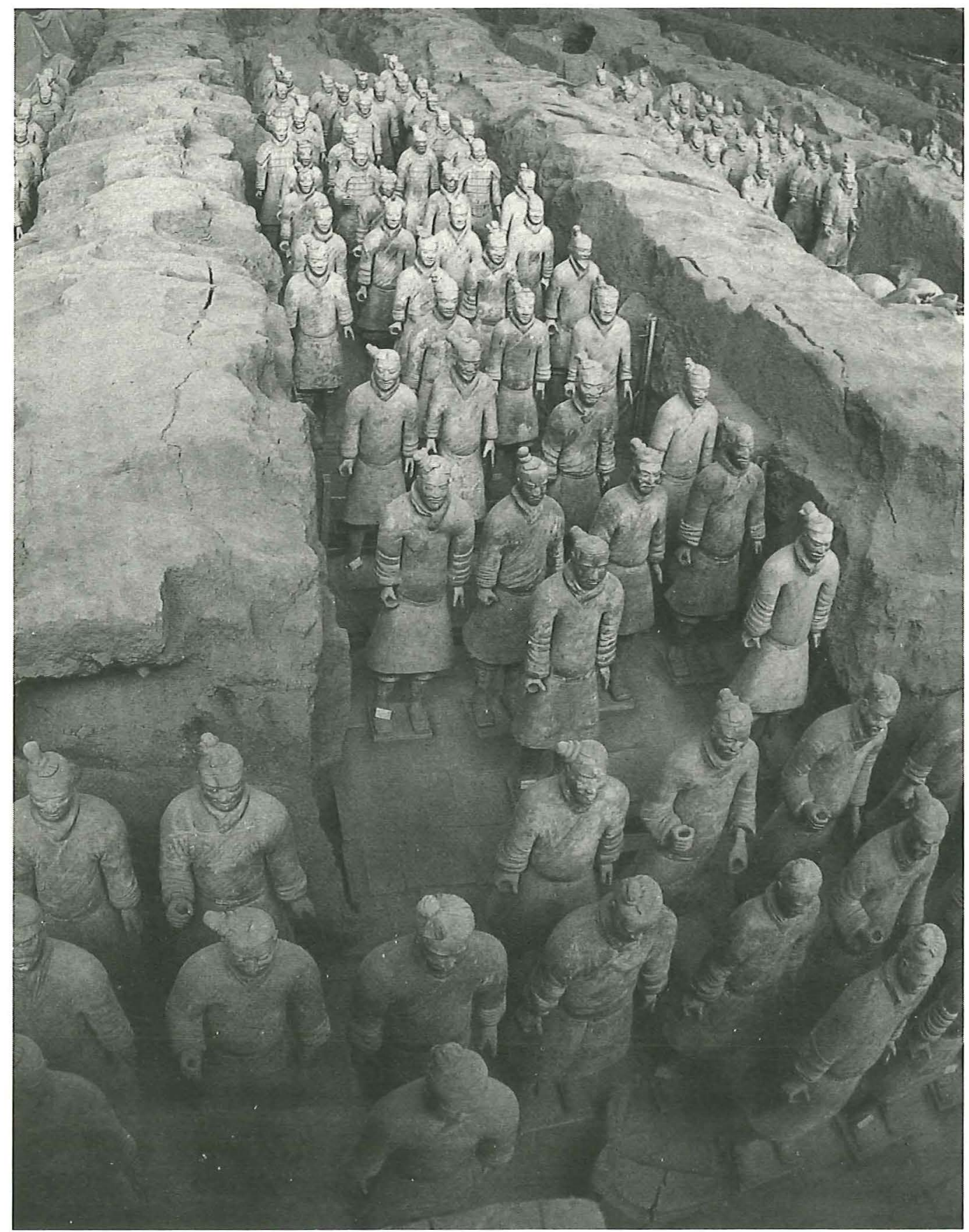


SU DONGHAI

78 encouraging all workers and staff members to conduct self-cultivation and ideological training. Self-cultivation includes not only setting up one's own noble ideal, but also dealing correctly with human relationships, particularly the relationship between individuals and the collective. Therefore, self-cultivation represents a moral practice with a wide intention. Comparing morality with legality, Chinese museums pay greater attention to the fostering of morality.

Chinese museum workers enjoy an intimate relationship among themselves. People working together in a small unit, know one another well and they behave just like members of a big family. Accordingly, strong affections exist side by side with deep contradictions. Adjusting the relationships among people can be achieved mostly by practising self-criticism on both sides. Raising people's moral quality to a higher level remains a good prescription for solving the contradictions among them and turning the passive factors into active ones. The professional zeal and good human relationships maintained by Chinese museum workers arise mainly from their self-cultivation in ideological and moral aspects.

Nevertheless, in the great torrent of reform and opening up to the outside world there are multiple outlooks regarding values which inevitably flow through the brains of Chinese museum workers. Thus, it is not enough now to rely solely on the moral force, efforts have been made to strengthen the legal construction in museums. This is another question which I am not going to discuss here.

In concluding the discussion on the problem of the philosophy of Chinese museums, I would like to stress one more point, that is, the philosophy of Chinese museums never represents a closed system. Although it took root in the soil of Chinese historical and revolutionary traditions, yet the Chinese museums absorbed the value outlooks of the Western museums at the very beginning of their foundations. Then, taking Marxism as its theoretical guide, the philosophy of Chinese museums is able to incorporate into itself valuable and progressive thoughts of diverse characters. For more than a decade, owing to the favourable conditions of reform and opening up to the outside world, Chinese museological circles have gained a deeper insight into the generality of museums of different countries, great attention has been paid to learning and studying the theoretical and practical experiences of the Western museums, and accordingly, the exchanges and co-operation with the museums in other countries have been strengthened.

\section{CHINA'S COMPREHENSION AND EVALUATION OF THE ECOMUSEUM AND NEW MUSEOLOGY}

China knows very little of the ecomuseum and new museology movement. Since it is a completely new but very famous school in the international museum circle, we museum workers have been paying close attention to it. As early as 1986, Chinese Museum - a quarterly published by the Chinese Society of Museums - started to print and introduce essays and news related to this movement. The magazine has a circulation up to 4000 . Its readers have had the chance to read Chinese editions of important papers written by George Henri 
Riviere, the founder of the ecomuseum movement as well as the Chinese editions of the articles in MUSEUM - a publication of UNESCO, the Round-Table Conference of the International Council of Museums held in Santiago, Chile in 1972; the international conference held in Montreal, Quebec, Canada in 1984 and its declaration; and the resolution of the New Museology International Academic Seminar held in Spain in 1987. Other Chinese publications have also printed similar reports.

China does have some knowledge of the first ecomuseum in France and a group of ecomuseums in Canada. In 1993, Nancy Fuller gave a minute description of the US Akchin Indian Community Ecomuseum in a slide talk while she was attending the Sino-US Museology Seminar held in China. Dr. Vinos Sofka, a Swedish museologist, and Dr. Peter van Mensch, a Dutch museologist, visited China in 1989 and 1993 respectively. Both of them exchanged their views on the ecomuseum and new museology with us. The visit of Andre Desvallées, a French museologist, and John Aage Gjestrum, a Norwegian ecomuseologist, in 1994 provided us with an opportunity for further understanding of the ecomuseum and the new museology movement. Even so, it is still right to say that China has only a superficial knowledge of this movement.

The Chinese people began their interest in the ecomuseum by looking into the environmental science. Chinese Museum published an article in 1986 called The Museum and Environmental Science by $\mathrm{Hu}$ Yanyan, a graduate student from the Department of Museology, Nankai University, Tianjin, China. Later, the quarterly also printed many articles including Museum and the Quality of the Environment by Zhao Songling, a curator of the China Geological Museum; Natural History Museum and Pale Environment and Environmentalism and the Museum by Zhen Shuonan, a curator of Beijing Natural History Museum. In 1990, Sun Xiao, a young worker at the Banpo Site Museum, Xian, suggested using ecology in the protection of cultural relics. Liu Shaoming, a researcher from Nanyang Museum, Henan, published an essay called My Humble Opinion of Museum Ecology. Liu put forwards a proposal for using the ecosystem to analyse the birth and development of a museum. Liu also suggested adopting the ecosystem in the study of the inner and outer balances of a museum. At the same time, Tu Xiaoyuan, a curator from Tianjin, published an article called The Relationship Between the Museum and the Community Cultural Environment. Between 1985 and 1988, a group of special museums was established in Guizhou Province. Among them, are three nationality village museums. In November 1986, I went to Huashishao Buyi Nationality Village Museum for an on-the-spot investigation. Located in remote mountains, the village still has an ancient setting and follows a traditional life style. Apart from Guizhou, such village museums can also be found in other provinces. Some people consider these village museums to be ecomuseums, but they are not ecomuseums in the real sense. However, the Chinese people now have a strong awareness of the environment and ecology, some people in museum circles have already made theoretical and practical studies of ecomuseology. 
80 Last, I would like to express some of my own opinions on the international ecomuseum and new museology movement. The initiation of such a movement in the sphere of international museology is a reflection of the people's growing awareness of the modern eco-environment. Because of the worsening ecological crisis, exhausted natural resources, a polluted environment and surplus population, the industrial society is in a predicament and unable to extricate itself. People are now weary of the industrial civilisation since it has created a bad environment, reduced our quality of living, manufactured too many machines and made our urban areas far more crowded and noisy. The public have a wish to return to nature and seek a simple and unsophisticated life. As a result, people are more concerned about modern ecological and environmental knowledge.

In 1971, UNESCO outlined a Man and Biosphere plan, more than 100 countries joined in this plan. Some museums even held exhibitions called Ecology in Action. This shows that modern ecological awareness has moved into an action stage. The appearance of the ecomuseum and new museology movement are a part of the new era. The birth of the ecomuseum and new museology movement is neither an accidental phenomenon nor the ideas of a few people. We must not devalue the historical background and social significance of such a movement. I myself respect the courage and spirit of its supporters.

Ecological civilisation will surely replace industrial civilisation in the next century and become the major civilisation in modern society. But industrial civilisation will not evaporate. Its essence will be carried on. In the future society, the ecomu- seum will definitely inherit and develop the cream of the traditional museum instead of discarding the latter completely. While the traditional museum will perfect itself by self-criticism. If the ecomuseum abandons the traditional museum like a woman who throws away the baby with the bathwater, it will no longer be a museum but only a place for cultural activity, just as Dr. Martin Schärer once told me. I have the same worry. If an ecomuseum and the new museology movement ignores the cream of the traditional museum, it will have stepped onto the road to Nihilism.

Evidently, the conditions for the spread of the ecomuseum do not yet exist. Efforts so far are only on a trial basis but it will surely have very good prospects in a future society with a highly ecological civilisation.

Translated from Chinese by An Laishun, Editor of Chinese Museum.

Su Donghai is Professor of History, curator of The Museum of Chinese Revolution and Editor in Chief of Chinese Museum. Graduated from Department of Philosophy, Beijing University. He has published The Evaluation on Chinese Museums (1981) and The Dictionary of Modern Chinese History (ed. 1994). Member of the Executive Council, Chinese Society of Museums.

Adr: The Museum of Chinese Revolution,

Tian An Men Square, Beijing 100006, China

Fax $+86-105129348$ 